\title{
Pre-Service Teachers' Conceptual Metaphors about Philosophy Course*
}

\author{
Mehmet YAPICI**
}

\author{
İlker KÖSTERELİOĞLU***
}

Received: 15 June 2014
Accepted: 07 November 2016

\begin{abstract}
The present study aims to reveal the conception of freshmen studying at Amasya University about philosophy course with the help of metaphors. Phenomenological design, which is a kind of qualitative research design, has been used for the study. The study group of the study is 162 freshmen students in the 2013-2014 semester year. Questionnaires were used to make students clarify philosophy course with metaphors. The metaphors related to philosophy were grouped and classified. In the study, content analysis technique was used to evaluate the gathered data. According to findings, the participants produced 35 valid metaphors related to philosophy course. After these metaphors had been analyzed in terms of common traits, they were grouped under five different notional categories. These categories are : "Philosophy as the source of unhappiness", "Philosophy as the source of epistemology", "Philosophy as the source of chaos", "Philosophy as the source of enlightenment", "Philosophy as the source of abstract thinking".
\end{abstract}

Keywords: Education, metaphor, philosophy, content analysis, teacher candidate.

\section{Extended Abstract}

Purpose and Significance: Philosophy, being the system of abstractions, is one of the most difficult fields to teach. Secondhand and negative information against philosophy make teaching it more difficult. In order to overcome these difficulties, firstly the attitudes of students as to the course and what they like/dislike must be described. The way to develop positive attitudes for philosophy must be making it understandable (Ergün \& Yapıc1, 2006).

One of the most convenient ways to understand what philosophy is or is not in terms of teacher candidates is to understand students' thoughts and emotions. One of the ways to understand the context is making descriptions with metaphors. Briefly, a metaphor is attributing meaning to a specific thing with respect to the other (Lakoff \& Johnson, 2005).

The most important side showing the success of earning is that it has a philosophy about the world and education. An Analytical Philosophy course must be included in teacher education programs in order to raise analytical thinker individuals of for future.

\footnotetext{
"This study was presented at "3. Ulusal Eğitim Programları ve Eğitim Kongresi” in Gaziantep, Turkey.

** Lecturer, Amasya University, Amasya, Turkey, myap1c1@amasya.edu.tr

**** Corresponding Author: Assist. Prof. Dr., Amasya University, Amasya, Turkey, ikostereli@ hotmail.com
}

\section{Citation Information}

Yapıcı, M., \& Kösterelioğlu, İ. (2016). Öğretmen adaylarının felsefe dersine ilişkin metaforları. Kuramsal Eğitimbilim Dergisi [Journal of Theoretical Educational Science], 9(4), 662-677. 
Methods: Phenomenological design, which is a kind of qualitative research design, has been used for the study. Phenomenology focuses on the phenomenon which we are aware but have no detailed information. Phenomenology constitutes a relevant research base for the studies analyzing the phenomenon whose meaning we cannot acquire and which we are not totally unfamiliar (Yıldırım \& Şimşek, 2006). The study group of the study is 162 freshmen students at Amasya University in 2013-2014 academic years. In order to determine the metaphors used by students to describe philosophy questions such as "Philosophy is like... Because it..." have been provided. Content analysis technique was used to evaluate the gathered data. Besides, the frequency values of the opinions were presented.

Results: According to findings, the participants have produced 35 valid metaphors related to philosophy course. After these metaphors have been analyzed in terms of common traits they have been grouped under five different notional categories. These categories are: "Philosophy as the source of unhappiness", "Philosophy as the source of epistemology", "Philosophy as the source of chaos", "Philosophy as the source of enlightenment", "Philosophy as the source of abstract thinking".

Discussion and Conclusions: Modern human is a creature who interrogate, criticize and change the values he/she produced and even the science whenever necessary. Philosophy becomes a memorized abstract information pile if it is presented as simple rational design and doctrines and if it is not related to update issued and events. Candidate teachers should meet philosophy and participate to the adventurous journey of philosophy. However, it can be defined that teachers are educated far from this point of view. As Güler (2008) stated, if the teachers are not educated with a philosophical base they will not perceive the basic concept of program and social change will not be gathered. These are consistent with the findings of the present study.

It can be stated that these general judgments can be reached when the study is dealt as a whole:

1. When the metaphors of philosophy as the source of unhappiness are analyzed it can be claimed that it is the reflection of presuppositions of student about philosophy course.

2. When the metaphors of philosophy as the source of epistemology are analyzed, it can be stated that the perception of students' base on a superficial suggestion as "philosophy is a bunch of knowledge".

3. When the metaphors of philosophy as the source of chaos are analyzed, it can be said that students regard philosophy course as a mental chaos.

4. When the metaphors of philosophy as the source of enlightenment are analyzed, it can be said that there are positive perceptions and it is full of promising context about the future of philosophy course. 
5. When the metaphors of philosophy as the source of abstract thinking are analyzed, it can be said that the students' thoughts are messy and they have difficulty in making sense of the problem. 


\section{Öğretmen Adaylarının Felsefe Dersine İlişkin Metaforları *}

Mehmet YAPICI**
İlker KÖSTERELIOĞLU***

Makale Gönderme Tarihi: 15 Haziran 2014

Makale Kabul Tarihi: 07 Kasim 2016

ÖZET: Bu araştırma, Amasya Üniversitesi’nde birinci sınıfına devam eden öğretmen adaylarının felsefe dersine ilişkin sahip oldukları algıları, metaforlar yardımıyla ortaya çıkarmayı amaçlamaktadır. Çalışmada nitel araştırma desenlerinden fenomonolojik (olgubilim) desen kullanılmıştır. Araştırmanın çalışma grubunu, 2013-2014 öğretim yılında birinci sınıf programına devam eden 162 öğrenci oluşturmaktadır. Araştırmada, öğretmen adaylarının felsefe dersini metoforlar yoluyla belirtmeleri için anket kullanılmıştır. Toplanan anketlerdeki felsefeye ilişkin metaforlar gruplara ayrılıp sınıflandırılmıştır. Bu çalışmada, elde edilen verilerin değerlendirilmesinde "içerik analizi" tekniği kullanılmıştır. Araştırmanın bulgularına göre, katılımcılar felsefe dersine ilişkin olarak toplam 35 adet geçerli metafor üretmiştir. Bu metaforlar daha sonra ortak özellikleri bakımından incelenerek beş farklı kavramsal kategori altında toplanmıştır. Bu kategoriler; "mutsuzluk kaynağı olarak felsefe", "epistemoloji kaynağı olarak felsefe", "kaos kaynağı olarak felsefe", "aydınlanma kaynağı olarak felsefe" ve "soyut düşünme kaynağı olarak felsefe" şeklinde belirlenmiştir.

Anahtar kelimeler: Eğitim, metafor, felsefe, içerik analizi, öğretmen adayı.

\section{Giriş}

Yunanca "Philosophia" teriminden kaynaklanan felsefe, "sevgi" (phillia) ve "bilgi, bilgelik" (sophia) sözcüklerinin birleşmesiyle oluşmuştur. Başlangıçta içinde bilgi bulunan tüm alanlarla ilgili araştırmalar felsefenin bütünselliği içerisinde görülmesine rağmen zamanla, bilimsel ve dinsel konular felsefeden ayrılmıştır. Yine de zaman içerisinde felsefe, bilim ve din konularının tamamıyla felsefeden kopamayacağı görüşü daha kabul görmüştür (Sözer, 2008). Ekiz (2013) felsefenin tanımlanmasının onun anlamını daralttığına vurgu yaparak böyle bir durumda çalışma yapan düşünürün kendi çalışma ve inceleme alanıyla duruma yaklaştığını, bunun yerine filozofların ne düşündükleri ve hangi soruları oluşturduklarına yönelmelerinin daha etkili olacağını belirtmektedir. Topdemir (2009), felsefeyi, doğal ve doğal olmayan her türlü varlık üzerine, düşünme, bilme, tanıma, öğrenme, anlama, anlamlandırma ve açıklama eylemi ve etkinliği olarak betimlemektedir.

Felsefe; günlük yaşamda çok sık kullandığımız bir kelime olmamasına rağmen kişiliğimiz, düşüncelerimiz, davranışlarımız ve etrafımızda yaşananlar, yaşam felsefemizin bir ürünüdür. Soğuk ve anlaşılması zor bir soyutlama olarak kabul edilen felsefe, bu yönüyle bize çok yakın olarak görülmektedir (Aydın, 2006). Bu nedenle bir toplumun yetiştirdiği bireylerde felsefeye yönelik bir algının olması en azından dünyayı anlamaya ve anlamlandırmaya yönelik bir çaba olarak gereklidir. Bu çabanın anlam ve değerinin karşıllğıını bulmasında öğretmenlere önemli bir rol düşmektedir.

Başarılı bir öğretmeni betimlemede önemli niteliklerden birisi, onun yaşadığ dünya ve eğitim hakkında bir felsefeye sahip olup olmamasıdır. Eğitimin toplumun

\footnotetext{
"Bu araştırma 3. Ulusal Eğitim Programları ve Eğitim Kongresi’nde sunulmuştur.

*** Sorumlu Yazar: Öğr. Gör., Amasya Üniversitesi, Amasya, Türkiye, myapıcı@amasya.edu.tr

**** Yrd. Doç. Dr., Amasya University, Amasya, Türkiye, ikostereli@hotmail.com
} 
değişim ve gelişiminde çok önemli bir rolü bulunmasına rağmen, toplumların değişime başarılı bir biçimde uyumu için öğretmenin öğrencilere aktaracağı teknik ve yöntemler yeterli değildir. Her toplumsal değişimin kendine özgü bir felsefi bağlamı vardır. Öğretmen bu felsefi bağlamı özümseyebilmelidir. Öğretmen bu şekilde yetişen bireylere teknikler ve yöntemler aktaran kişi durumunda olmaktan çıkarak onlara sosyal ve dünya ile ilgili değerler aktaran kişi konumuna ulaşabilmelidir.

\section{Metafor nedir?}

Metafor, bireylerin kendi dünyalarını anlamalarına ve yapılandırmalarına yönelik güçlü bir zihinsel haritalama ve modelleme mekanizmasıdır (Arslan \& Bayrakçı, 2006). Boostrom (1998)'e göre; metaforlar bir bakış açısının yaratıcı söylemi olarak kabul edilmektedir. Metafor; farklı kaynaklarda ve bilim alanlarında farklı terimlerle karşılanmaktadır. Sosyoloji ve Felsefede analoji, Edebiyat ve Dilbilim alanında mecaz, ödünçleme, istiare, Eğitimbilim alanında ise daha çok benzetme anlamında kullanılmaktadır. Ancak, bunların hiçbiri tam olarak metaforik düşünceyi açıklayamadığı düşünüldüğü için metafor kavramının kullanımı tercih edilmektedir.

Metafor kelimesi, yunanca "Metapherein" kelimesinden türemiştir. "Meta" değiştirmek, "pherein" ise taşımak, anlamındadır (Levine, 2005). Metafor, bir düşünce ve görme biçimidir (Morgan, 1998). Günümüzde söz sanatı olarak daha çok tanınan metafor (Salman, 2003), her dilde, anlatımı güçlendirmek, canlı kılmak için yararlanılan söz sanatlarından biri olarak, benzetme demektir. Benzetme; bir nesnenin niteliğini, bir eylemin özelliğini daha iyi anlatabilmek için bir başka nesne ve eylemlerden yararlanarak, onu anımsatma yoluyla gerçekleştirilir (Aksan, 1998). Öz olarak metafor bir şeyi başka bir şeye göre anlamlandırmak, ifadelendirmektir (Lakoff \& Johnson, 2005). Metaforlar insanın doğayı ve çevresini anlamasının, anlamsız gibi görünen nesnel gerçeklikten belirli yorumlar yoluyla anlamlar çıkarmasının, yaşantı ve deneyime anlam kazandırmanın araçları olarak "bilmeye" de olanak sağlar (Yıldırım \& Şimşek, 2006).

Metafor; bir şeyi veya bir fikri ona çok benzer niteliklere sahip başka bir şey ile genelde "gibi", "benzer" sözcüklerini kullanmaksızın istenen tanımlamayı yapmak, anlatıma üslup güzelliği ve kolaylığı katmak için kullanılan sözcük ya da sözcük kümesidir. Başka bir deyişle metafor; bir kavramı, kelimeyi, terimi, olguyu daha güzel ve iyi anlatmak amacıyla, başka bir anlamda olan bir sözcükle, ilgi kurularak benzetme yoluyla kullanılmasidır (Aydın, 2006).

Bir şeyin metafor olarak kabul edilebilmesi için üç sorunun cevaplandırılması gerekir; bir; metaforun konusu nedir? iki; metaforun kaynağı nedir? üç; metaforun kaynağından konusuna aktarılması istenen (düşünülen) özellikler nelerdir (Forceville, 2002)? Örneğin felsefe çıkmaz sokak gibidir cümlesine bakalım. Felsefe metaforun konusu, çıkmaz sokak metaforun kaynağıdır. Öğretmen adayı; kaynaktan konuya şu düşünceleri aktarmak istiyor olabilir: "kişi ne yaparsa yapsın, ne kadar uğraşırsa uğraşsın, felsefenin ona katacağı somut bir şey yoktur, eninde sonunda boşu boşuna çaba harcadığını görecektir”. Öğretmen adaylarının bu bağlamda, metafor kavramını bilinçli olarak kullanmayı öğrenmeleri ve yorumlayabilmeleri, onları, eğitim-öğretim 
ortamında öğrencileri anlamada, duygu ve düşüncelerini yorumlamada daha nitelikli ve donanımlı kılacağı söylenebilir.

Literatürde öğretmen adaylarının felsefe dersine ilişkin oluşturdukları metaforlara yönelik araştırmacıların ulaşabildiği bir çalışma olmamakla beraber felsefe dersine ilişkin çalışmaların öğretmen adaylarının felsefi tercihleri üzerinde yoğunlaştığ 1 görülmektedir (Doğanay \& Sarı, 2003; Duman \& Ulubey, 2008). Bu yönde yapılan araştırmalara gerekçe olarak eğitimle ilgili kararlar alırken bilinçli ya da bilinçsizce öğretmenlerin sahip oldukları felsefi tercihleri dolayısıyla da eğitim felsefesine göre davrandıkları gösterilmektedir (Çağırgan \& Karaduman, 2010).

Felsefe, bir soyutlamalar dizgesi olarak, öğretiminin yapılması en zor alanlardan birisidir. Buna bir de felsefeye karşı kulaktan dolma, olumsuz bilgiler eklenince, felsefe öğretimi daha da zorlaşmaktadır. Bütün bu zorlukların üstesinden gelmek için, öncelikle bu dersi alan öğrencilerin derse karşı tutumlarının, neleri beğenip beğenmediklerinin betimlenmesi gerekir. Felsefeye karşı olumlu tutum geliştirmenin yolu, onu anlaşılır kılabilmek olmalıdır (Ergün \& Yapıc1, 2006).

Felsefe bir bakıma sorulara ve problemlere getirilen yanıtlar ve çözüm denemeleri, bu yanıt ve çözüm denemelerinin yol açtığ 1 yeni soru ve problemler topluluğudur (Özlem, 1997). Felsefenin asıl görevi soru sormak, araştırmak ve bu araştırmaları devam ettirmektir. Felsefe, belli bir aydınlar grubunun, insandan ve yaşamdan kopuk, anlaşılmaz kurgular ürettikleri bir bilgi dalı değildir. Yaşamla felsefe arasındaki gerçek bağı göremeyen ya da kuramayan biri felsefeci olamaz.

Öğretmen adayları açısından felsefenin ne olup olmadığının anlaşılması için en uygun yollardan biri de doğrudan onların düşünce ve duygularını anlamaya çalışmaktır. Bu bağlamı anlamanın yollarından biri de metaforlar üzerinden betimleme yapmaktır. $\mathrm{Bu}$ araştırma, öğretmen adaylarının "felsefe dersine" ilişkin sahip oldukları algıları metaforlar yoluyla ortaya çıkarmak amacıyla gerçekleştirilmektedir. Bu genel amaç çerçevesinde aşağıdaki sorulara yanıt aranmaktadır.

1.Öğretmen adaylarının "felsefe dersine" ilişkin sahip oldukları metaforlar nelerdir?

2.Öğretmen adayları tarafindan ortaya konan metaforlar ortak özellikleri açısından hangi kategoriler altında toplanmaktadır?

\section{Yöntem}

\section{Araştırmanın Modeli}

Öğretmen adaylarının felsefe dersine ilişkin sahip oldukları algıları, metaforlar aracılığıyla belirlemeyi amaçlayan bu çalışmada nitel araştırma desenlerinden fenomonolojik (olgubilim) desen kullanılmaktadır. Olgubilim deseni, farkında olunan ama derinlemesine ve ayrıntılı bir anlayışa sahip olunmayan olgulara odaklanmaktadır. Olgubilim, bize tümüyle yabancı olmayan aynı zamanda da tam anlamını kavrayamadığımız olguları araştırmayı amaçlayan çalışmalar için uygun bir araştırma zemini oluşturur (Yıldırım \& Şimşek, 2006). 


\section{Çalışma grubu}

Araştırmanın çalışma grubunu, Amasya Üniversitesi'nin 2013-2014 öğretim yılında birinci sınıf programına devam eden 162 öğrenci oluşturmaktadır. Çalışma grubu olarak birinci sınıf öğrencilerinin seçilmesinin nedeni, ortaöğretimde felsefe dersi almış olmaları ve derse ilişkin bilgilerini hatırlama olasılıklarının yüksek olmasıdır. Böylece belleklerindeki felsefe dersine ilişkin bilgilerinin metafor üretmede ve üretilen metaforların gerçekliğinin daha yüksek olma olasılığıdır.

Öğretmen adaylarına araştırmanın amacı anlatılarak, katılımın zorunlu olmadığ1 ve kimlik bilgilerinin özellikle yazılmaması gerektiği hatırlatılarak uygulamaya geçilmiştir. Araştırmanın çalışma grubunu; sınıf öğretmenliğinden (32 kız, 26 erkek) 58, Türkçe Öğretmenliğinden (29 kız, 34 erkek) 63, Sosyal Bilgiler öğretmenliğinden (19 kız, 22 erkek) 41 öğretmen adayı oluşturmaktadır.

\section{Veri Toplama Aracı}

Araştırmada, öğretmen adaylarının felsefe dersine ilişkin hangi metaforları kullandıklarını ortaya çıkarmak amacıyla; "Felsefe ... gibidir. Çünkü ..." şeklinde görüşlerini yazabilecekleri anketler verilmiştir. Anketin doldurulması için 15 dakika zaman verilmiştir. Toplanan anketlerdeki felsefeye ilişkin metaforlar analiz edilerek; aynı anlamlara gelen metaforlar, öğretmen adaylarının "çünkü” den sonra yaptıkları açılamalar da dikkate alınarak kategorilere dönüştürülmüştür.

\section{Verilerin Çözümlenmesi}

Bu çalışmada, elde edilen verilerin değerlendirilmesinde "içerik analizi”" tekniği kullanılmıştır. İçerik analizinde temel amaç, toplanan verileri açıklayabilecek kavramlara ve ilişkilere ulaşmaktır. İçerik analizinde temelde yapılan işlem, birbirine benzeyen verileri belirli kavramlar ve temalar çerçevesinde bir araya getirmek ve bunları okuyucunun anlayabileceği bir biçimde organize ederek yorumlamaktır (Yıldırım \& Şimşek, 2006). Bu bağlamda çalışmada veri analizi için şu yol izlenmiştir:

Adlandırma aşaması. Bu aşamada öğrencilerin yazdığı metaforlar tek tek adlandırılarak listelenmiştir.

Kategori oluşturma aşaması. Öğrencilerin ürettiği metaforlar kavramsal kategoriler altında gruplandırılmıştır. Her kategori altında yer alan metaforlara, metafora ilişkin gerekçeler eklenmiştir. Metaforların gerekçeleri yazılırken; aynı anlama gelen gerekçeler anlamı bozmayacak şekilde tek bir gerekçeye dönüştürülmüştür. Bazı metafor gerekçelerinde de birleştirme şu şekilde gerçekleştirilmiştir:

Örnek 1: Mutsuzluk kaynağ1 olarak felsefe kategorisinde yer alan "kara sevda" metaforunun gerekçeleri iki ayrı gerekçeye dönüştürülmüş sonra da ikisi tek cümle olarak ifade edilmiştir. "Var olduğunu bilirsin ama dokunamazsın, ulaşamazsın" gerekçesi şu iki gerekçenin birleştirilmesinden oluşturulmuştur: "var olduğunu bilirsin ama dokunamazsın" ve "ona ulaşılamaz mümkün değil". 
Örnek 2: Epistemoloji kaynağı olarak felsefe kategorisinde yer alan "atık (çöp)" metaforunun 3 ayrı gerekçesi tek gerekçeye dönüştürülmüştür. "Atan için değersizdir, geçimini ondan sağlayan için eşsiz ve paha biçilemez bilgidir" şeklindeki gerekçe; şu üç ayrı gerekçeden birleştirilmiştir: "çöpe atan için değersiz bir şeydir", "geçimini sağlayan için hazinedir" ve "yanlışlıkla çöpe atılmış eşsiz ve paha biçilemez bir bilgi".

Geçerlik ve güvenirlik aşaması. Çalışmada, araştırmanın bütün süreçleri ile adım adım anlatılarak geçerliliği sağlanmıştır. Güvenirlik için, araştırmada ulaşılan beş kavramsal kategori altında verilen metaforların, kavramsal kategorileri temsil edilip edilmediğinin anlaşılması için uzman görüşüne başvurulmuştur. Bu amaç doğrultusunda uzman öğretim üyesine 35 adet metafor ve beş kategoriden oluşan iki liste verilmiştir. Uzman öğretim üyesi, metaforlarla kategorileri eşleştirmiştir. Daha sonra, uzman öğretim üyesinin eşleştirmesi ile araştırmacıların eşleştirmesi karşılaştırılarak uyuşum yüzdesine bakılmıştır. Miles ve Huberman'ın (1994) güvenirlik formülü kullanılarak (Güvenirlik = görüş birliği / görüş birliği + görüş ayrıllğı), araştırmanın güvenirliği 0.94 olarak bulunmuştur. Güvenirlik hesaplamasındaki uyuşum yüzdesi 70 olduğunda güvenirlik yüzdesine ulaşılmış kabul edilir (Yıldırım \& Şimşek, 2006).

Frekansların Hesaplanarak Yorumlanması Aşaması. $\mathrm{Bu}$ aşamada, metaforların frekansları çıkarılarak kavramsal kategoriler altında yorumlanmıştır.

Katılımcıların her birinin "Felsefe ... gibidir, çünkü ..." ibaresini tamamlamasıyla elde edilen ham veriler, hem nitel hem de nicel veri çözümleme teknikleri kullanılarak analiz edilmiştir. Araştırmanın bulgularına göre, katılımcılar felsefe dersine ilişkin olarak toplam 53 adet geçerli metafor üretmiştir. Ancak bazı metaforların gerekçeleri aynı ana fikri içerdiği için metaforlar en çok kapsayıcı olan metafor altında toplanarak metafor sayısı 35'e indirilmiştir. Bu metaforlar daha sonra ortak özellikleri bakımından incelenerek beş farklı kavramsal kategori altında toplanmıştır. $\mathrm{Bu}$ kategoriler; "mutsuzluk kaynağı olarak felsefe", "epistemoloji kaynağı olarak felsefe", "kaos kaynağ1 olarak felsefe", "aydınlanma kaynağı olarak felsefe" ve "soyut düşünme kaynağı olarak felsefe" şeklinde belirlenmiştir. Çalışmadan elde edilen verilerin frekansları hesaplanarak yorumlanmıştır. 


\section{Bulgular ve Yorum}

\section{Mutsuzluk Kaynağı Olarak Felsefe}

Tablo 1

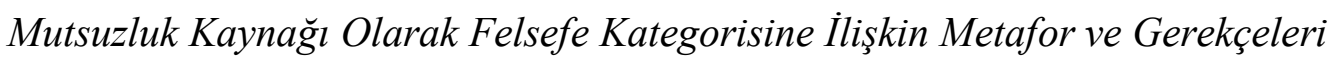

\begin{tabular}{l|l|l}
\hline Metafor & f & Gerekçe \\
\hline Kara Sevda & 7 & Var olduğunu bilirsin ama dokunamazsın, ulaşamazsın \\
\hline Savaş & 5 & Felsefe düşüncelerin savaştığı ve kazananın olmadığı bir süreçtir \\
\hline İmaj & 3 & Felsefe konuşmayı süsleyen bir aksesuardır, gösterişli ama gereksiz. \\
\hline Beklemek & 3 & Gelip gelmeyeceğini bilemezsin sen yine de beklersin ve çoğunlukla gelmez \\
\hline Dinsizlik & 1 & İnsanı inançtan uzaklaştırır \\
\hline
\end{tabular}

Mutsuzluk kaynağı olarak felsefe metaforlarına bakıldığında, öğrencilerin felsefe dersine ilişkin önyargılarına ilişkin düşüncelerinin bir yansıması olduğu söylenebilir. Öğrencilerden yedisinin "kara sevda" metaforunda ileri sürdüğü gerekçeye bakıldığında; felsefenin ulaşılmaz ve anlaşılamaz olduğunu ilişkin bir önyargının olduğu görülmektedir. Bunun nedenin dersin içeriğinin soyut ve felsefe öğretiminin kademe (ortaöğretim) öğrencilerinin bilişsel ve duyuşsal düzeyine uygun tasarlanmamasından kaynaklandığ 1 söylenebilir. Benzer şekilde "savaş" metaforunda da felsefe dersinin filozofların geçmişten gelen kronolojik kuramlar yığınına dönüştürülmesinden kaynaklandığı ileri sürülebilir.

Mutsuzluk kaynağı olarak felsefe kategorisinin, felsefe dersinin kronolojik bir "kim dedi, ne zaman dedi, ne söyledi" bağlamı içinde kurgulanmasından kaynaklandığ söylenebilir. Bu nedenle, felsefe dersinin güncel ve toplumsal yaşamla ilişkilendirilerek ele alınmasının dersin verimlik ve etkililiğini artırabileceği ileri sürülebilir. 


\section{Epistemoloji Kaynağı Olarak Felsefe}

Tablo 2

Epistemoloji Kaynă̆ı Olarak Felsefe Kategorisine İlişkin Metafor ve Gerekçeleri

\begin{tabular}{l|l|l}
\hline Metafor & f & Gerekçe \\
\hline Bilinmeyen & 11 & Tanımlanamayan bir bilgi yığını \\
\hline Domino Taşı & 3 & Birbirine bağlı yığılmalı sonsuz bir bilgi birikimi \\
\hline Atık (Çöp) & 3 & $\begin{array}{l}\text { Atan için değersizdir, geçimini ondan sağlayan için eşsiz ve paha } \\
\text { biçilemez bilgidir. }\end{array}$ \\
\hline Limon & 1 & İlk anda verdiği tad buruktur, öğrendikçe lezzet vermeye başlar \\
\hline
\end{tabular}

Epistemoloji kaynağı olarak felsefe metaforlarına bakıldığında, öğrencilerin felsefe dersine ilişkin algılarının, felsefe eşittir bilgi yı̆̆ını şeklinde yüzeysel bir önermeye dayandığı söylenebilir. Öğrencilerden 14'ünün "bilinmeyen" ve "domino taşı" metaforuna ilişkin ileri sürdüğ̈̈ gerekçelere bakıldığında; felsefenin kronolojik bilgiden öteye gidemediği anlaşılmaktadır.

\section{Kaos Kaynağı Olarak Felsefe}

Tablo 3

Kaos Kaynă̆g Olarak Felsefe Kategorisine İlişkin Metafor ve Gerekçeleri

\begin{tabular}{l|l|l}
\hline Metafor & $f$ & Gerekçe \\
\hline Çıkmaz sokak & 14 & Sonucu olmayan boş bir uğraş \\
\hline Arayış & 11 & Hiç bitmeyen ve neyi aradığını bile bilmediğin şey \\
\hline Delilik & 7 & Sürekli birbiriyle zıtlaşan bir yaşam sıkıntısı \\
\hline Sonsuz karanlık & 7 & Derinliği ve genişliği ürkütücüdür \\
\hline Oyun Hamuru & 3 & Nasıl düşünürsen ona göre form ve biçim alır \\
\hline Hindi & 1 & Boş boş düşünmek \\
\hline Türk Kızı & 1 & İkisi de anlaşılamaz \\
\hline Labirent & 1 & Doğru yolu bulmak zordur \\
\hline
\end{tabular}

Kaos kaynağı olarak felsefe metaforlarına bakıldığında; öğrencilerin felsefe dersini zihinsel bir kaos olarak gördükleri söylenebilir. Öğrencilerin çıkmaz sokak metaforunda ileri sürdükleri "sonucu olmayan boş bir uğraş" gerekçesi, felsefe dersi eğitiminin ve öğretim programının sorgulamaya ve anlamlandırmaya yönelik bir kurguda planlanmadığ1 ve yürütülmediği düşüncesini oluşturmaktadır. Felsefe dersinin öğrencileri "boş uğraş" izlenimi yaratmaktan uzaklaştırıp, yaşamı ve insanı 
anlamlandırmaya yöneltmesi için ne yapılması gerektiği üzerinde düşünmemiz bir zorunluluk olarak görülmelidir.

"Delilik" metaforu ise felsefe dersinin anlamı üzerinde dolaşan bir kara bulut gibidir. Ve çoklukla felsefenin akıl sağlığını tehdit ettiğine ilişkin söylemlerin bazen akademik düzeyde de dillendirildiği görülebilmektedir. Bu algının yerleşmesinin nedeni olarak da; yine felsefe dersinin güncel yaşam sorunlarından uzak, kronolojik bilgi yığını olarak tasarlanmasından kaynaklandığı söylenebilir. Benzer şekilde "sonsuz karanlık" metaforu da aynı bağlamda yorumlanabilir. Bu bölümdeki tek olumlu ya da iyimser yorum yapılabilecek metafor "oyun hamuru" metaforu ve buna ilişkin ileri sürülen gerekçedir. Gerçekten de felsefe dersinin kurgusu ve öğretim programının, felsefe dersine ilişkin olumsuz yargılar oluşturan bir oyun hamuru olduğu söylenebilir.

\section{Aydınlanma Kaynağı Olarak Felsefe}

Tablo 4

Aydınlanma Kaynă̆ Olarak Felsefe Kategorisine İlişkin Metafor ve Gerekçeleri

\begin{tabular}{l|l|l}
\hline Metafor & $f$ & Gerekçe \\
\hline Yürüyüş & 9 & Önce emekler sonra yürümeye başlar insan, felsefe de böyledir. \\
\hline Okyanus & 6 & Büyük ve zengin düşüncelerin toplandığı yer \\
\hline Dünya & 3 & Farklılıkları içinde barındıran zengin ve zevkli bir bütün \\
\hline Çocuk & 3 & Hep merak eder \\
\hline Değişim & 3 & Sürekli ve durmadan akıp giden sonsuz bir nehir \\
\hline Ağaç & 3 & Her kış öldü derken, her baharda yeniden doğar \\
\hline Güneş & 3 & O almadan yaşam olamaz \\
\hline Can Simidi & 3 & Boğulurken ne kadar gerekli olduğu anlaşılan şey \\
\hline Isırgan Otu & 2 & Dokunduğunda canın yanar ama her derde devadır \\
\hline İnci & 1 & Sonsuz bir derinlikte seni bekleyen eşsiz ve değerli şey \\
\hline Işık & 1 & Felsefe yaşamı aydınlatır. \\
\hline
\end{tabular}

Aydınlanma kaynağ 1 olarak felsefe metaforlarına bakıldığında; felsefe dersine ilişkin olumlu yargıların yer aldı̆̆ 1 , felsefe dersinin geleceğine ilişkin umut verici bir bağlamın ileri sürüldüğü gerekçelerle dolu olduğu görülmektedir. "Yürüyüş" metaforunda felsefenin uzun ve emek isteyen bir uğraş alanı olduğu vurgusu dikkat çekerken, "okyanus" metaforu felsefenin derinliğinin ve yoğunluğunun korkulacak bir şey değil, yaşama değer katan bir zenginlik olduğu gerekçesi ile dillendirilmektedir. "Güneş" metaforu ise felsefeye ilişkin umutlarımızı diri tutan bir iyimserlik aşılamaktadır. 


\section{Soyut Düşünme Kaynağı Olarak Felsefe}

Tablo 5

Soyut Düşünme Kaynăğ Olarak Felsefe Kategorisine İlişkin Metafor ve Gerekçeleri

\begin{tabular}{l|l|l}
\hline Metafor & $f$ & Gerekçe \\
\hline Gözlük & 3 & Neye bakarsan onu görürsün \\
\hline Kazanç & 2 & Ruhsal ve düşünsel seviyeyi yükselten bir araç \\
\hline Kılavuz & 2 & Sorulduğunda doğru yolu gösteren bir rehberdir \\
\hline Ayna & 2 & Eğer istersen soyut varlığını görebilirsin \\
\hline Boş sayfa & 2 & Herkesin kendine göre dolduracağı boş beyaz bir sayfa \\
\hline Yap-Boz & 2 & $\begin{array}{l}\text { Bütün parçaları birleştirmeden felsefe bilinemez, güzelliği bütün ortaya } \\
\text { çıtığında anlaşılır. }\end{array}$ \\
\hline Bulmaca & 1 & \begin{tabular}{l} 
İlk anda zordur, çözmeye başladıkça eğlenceli ve zevkli hale gelir \\
\hline
\end{tabular}
\end{tabular}

Soyut düşünme kaynağı olarak felsefe metaforlarına bakıldığında; düşüncelerin dağınık olduğu izlenimi oluşmaktadır. Felsefenin bir soyutlama olduğu ilginç bir şekilde somut nesne ve nitelikler üzerinde gerekçelendirilmektedir. Kısaca felsefenin öğrencilerin zihinsel tasarımında bir soyutlama olarak bilindiği ancak bunun bilgi düzeyinde inşa edildiği görülmektedir. Soyutlama imgesinin somut bir algıya dönüştürüldüğü söylenebilir.

\section{Sonuç ve Tartışma}

Öğrencilerin felsefe dersine ilişkin sahip oldukları algıları, metaforlar yardımıyla ortaya çıkarmayı amaçlayan bu çalışmada, katılımcılar felsefe dersine ilişkin olarak toplam 35 adet geçerli metafor üretmiştir. Bu metaforlar daha sonra ortak özellikleri bakımından 5 farklı kavramsal kategori altında toplanmıştır. Bu kategoriler; "mutsuzluk kaynağı olarak felsefe", "epistemoloji kaynağı olarak felsefe", "kaos kaynağı olarak felsefe", "aydınlanma kaynağı olarak felsefe" ve "soyut düşünme kaynağı olarak felsefe" şeklindedir.

Epistemoloji kaynağı olarak felsefe metaforları incelendiğinde öğrencilerden 14'ünün "bilinmeyen" ve "domino taşı" metaforuna ilişkin ileri sürdüğü gerekçelere bakıldığında; felsefenin kronolojik bilgiden öteye gidemediği anlaşılmaktadır. Oysa felsefe bir bakıma sorulara ve problemlere getirilen yanıtlar ve çözüm denemeleri, bu yanıt ve çözüm denemelerinin yol açtığı yeni soru ve problemler topluluğudur (Özlem, 1997). Felsefenin asıl görevi soru sormak, araştırmak ve bu araştırmaları devam ettirmektir.

Kaos kaynağı olarak felsefe metaforlarına bakıldığında; öğrencilerin felsefe dersini zihinsel bir kaos olarak algılamaktadır. Çağımızda birçok sistem insanın olayları gerçek yüzüyle görmesini, anlamasını, yorumlamasını ve sorunları çözmesini engelleyen paradigmalardan oluşmaktadır. İdeolojiler, dinler, ekonomik sistemler, güçlü 
devletler, tek boyutlu öğretiler vs. basın-yayın ve eğitim kurumları aracılığıyla insanları istedikleri gibi şekillendirip özgür düşünmelerini engellemektedirler. Oysa felsefe her devirde düşünmeyi, tartışmayı, eleştirmeyi, anlamlı bir biçimde "evet" ya da "hayır" demeyi, özgür ve özerk seçim yapıp karar vermeyi öğretecek düşünce sistemleri olarak ortaya çıkmıştır. Düşünmeyi öğrenememiş, felsefe geleneği olmayan toplumlarda kolay tanımlar ve hazır formüller, büyük kitlelerce hemen benimsenmektedir (Arat, 1994). Felsefe bunun bir parçası olmak yerine, bu kaosu bitiren bir işlevle donatılmalıdır.

Aydınlanma kaynağı olarak felsefe metaforlarına bakıldığında; felsefe dersine ilişsin "yürüyüş", "okyanus" ve "güneş" gibi olumlu benzetmelerin yapılması, felsefe dersinin geleceğine ilişkin umut verici bir bağlam oluşturmaktadır. Kuçuradi (1996)’ye göre felsefe öğretimi, kişilere insanın çeşitli olanaklarının farklı değerlerini gösteren, bu bilgilerin ışığında kendilerini görebilme imkân tanıyan; kendi olanaklarını görebilme ve geliştirebilmelerine, temel amaçlarını oluşturmalarına, yaşamdan ne istediklerini belirlemelerine ve kendi yollarını çizebilmelerine yardımcı olan bir eğitim alanıdır.

Soyut düşünme kaynağı olarak felsefe dersine ilişkin oluşturulan metaforlar incelendiğinde öğretmen adaylarının düşüncelerin dağınık olduğu izlenimi oluşmaktadır. Ergün ve Yapıcı'nın (2006) araştırmasına göre; öğrencilerin \%95'i felsefe dersini oluşturan konuların (içerik) çok soyut olduğunu ileri sürmektedir. Felsefe dersini alan öğrenciler, yaş dönemleri itibari ile soyut işlemler döneminde olmalarına rağmen, felsefe dersi içeriğini algılamada güçlük çekmelerini doğal karşılamak gerekir. Bunun nedeni, ilköğretimden itibaren, derslerin işlenişinin ezberci ve bilgi nakletmeye dayalı bir kurgudan ibaret olmasıdır. Felsefe dersi içeriği itibari ile üst düzey soyutlama, kavram ve kuramlardan oluştuğu için, ders öğretmenlerinin öğrencilerinin bilişsel gelişim düzeylerinin farkında olarak, dersi somutlaştırmaları ve güncel yaşamla bağını kurmaları gerekir. Konuların anlaşılmaz derecede soyutluğu, öğrencileri, felsefe'ye karş1 olumsuz tutum geliştirmeye yönlendirebilmektedir. Felsefe'ye karş1 geliştirilen olumsuz tutum ise, toplumsal düşünme ve analitik sorgulama becerilerinin körelmesi açısından ürkütücü ve gelecek açısından kaygı verici bir durum olarak düşünülebilir.

Felsefe eğitiminden beklenen, insanın özgün, bağımsız ve mantıklı düşünme yeteneğini geliştirmektir. İnsanoğlu dışında hiçbir varlık kendi varlığı veya kendini kuşatan varlıklar karşısında merak ve hayrete düşmemiştir. İnsan; düşünme, şüphe, merak, kendini ve çevresini anlamaya çalışma ve sorgulama özelliği ile diğer canlılardan ayrılmaktadır (Millî Eğitim Bakanlığı, 2009). Oysa uygulamaya bakıldığında; antik dönem filozoflarının düşünce sistemleri, günümüzle bağlantı kurulmadan verildiği için felsefe dersi sıkıc1, soyut, ezberlenmek zorunda kalınan bilgiler yığını haline gelmektedir. Oysa ulusların ilerlemesi, insanların düşünce ve araştırma özgürlüğüne bağlıdır. Felsefe de insanlara düşünmeyi öğretmelidir. Çağdaş insan kendi ürettiği değerleri, hatta bilimi bile tekrar tekrar sorgulayan, eleştiren ve gerektiğinde değiştiren bir canlıdır.

Felsefe, sadece ham bilgiler ve öğretiler olarak sunulur, güncel konu ve olgu/olaylarla doğru şekilde ilişkilendirilemezse; ezberlenen ve günlük hayatta karşıllı̆ı bulunamayan soyut bilgiler yı̆̆ını haline gelir. Öğretmen adaylarının felsefenin yol 
göstericiliğinde hareket edebilmesi için felsefe ile tanışması ve felsefenin dinamik serüveninde yolculuk yapması gereklidir. Oysaki eğitim politikalarının uygulayıcısı ve aktarıcısı olarak yetiştirilen öğretmenlerin bu anlayıştan uzak yetiştiği ortaya çıkan metaforlara bakılarak da savunulabilir. Güler (2008) felsefi temelden yoksun öğretmenlerin yetiştirilmesi durumunda; öğretmenin yürütülen programların temel mantığını kavrayamayacağını ve toplumsal değişimin sağlanamayacağ vurgu yapmaktadır.

Araştırmaya, bir bütün olarak bakıldığında, şu genel yargılara ulaşıldığı söylenebilir:

1.Mutsuzluk kaynağı olarak felsefe metaforlarına bakıldığında, öğrencilerin felsefe dersine ilişkin önyargılarının bir yansıması olduğu söylenebilir.

2.Epistemoloji kaynağı olarak felsefe metaforlarına bakıldığında, öğrencilerin felsefe dersine ilişkin algılarının, felsefe eşittir bilgi yığını şeklinde yüzeysel bir önermeye dayandığı söylenebilir.

3.Kaos kaynağı olarak felsefe metaforlarına bakıldığında; öğrencilerin felsefe dersini zihinsel bir kaos olarak gördükleri söylenebilir.

4.Aydınlanma kaynağı olarak felsefe metaforlarına bakıldığında; felsefe dersine ilişkin olumlu yargıların yer aldığı, felsefe dersinin geleceğine ilişkin umut verici gerekçeler ileri sürüldüğü görülmektedir.

5.Soyut düşünme kaynağı olarak felsefe metaforlarına bakıldığında; öğrencilerin düşüncelerinin dağınık olduğu ve sorunu anlamlandırmada güçlük çektikleri söylenebilir.

Araştırmadan elde edilen bulgular doğrultusunda şu öneriler ileri sürülebilir:

1.Felsefe derslerinin kronoloji bilgisi olmaktan çıkarılarak, güncel yaşam sorunlarının tartışıldığı bir derse dönüştürülmesi gerekir.

2.Felsefe derslerinin sorulara yanit aranan bir ders kurgusundan ziyade soru sormayı teşvik eden, beyin firtınası yaratan bir ders olarak kurgulanması gerekir.

3.Felsefe dersi öğretim programlarının derse ilişkin olumlu tutum geliştiren etkinliklerle yeniden gözden geçirilmesi gerekir. 


\section{Kaynakça}

Aksan, D. (1998). Dilbilim seçkisi: günümüz dilbilimiyle ilgili yazılardan çeviriler. Ankara: TDK Yayını.

Arat, N. (1994). Felsefe eğitimi. Abece, 100, 27-28.

Arslan, M. M. \& Bayrakçı, M. (2006). Metaforik düşünme ve öğrenme yaklaşımının eğitim-öğretim açısından incelenmesi. Milli Eğitim, 35(171), 100-108. http://dhgm.meb.gov.tr/yayimlar/dergiler/Milli Egitim Dergisi/171/index3 icindekiler.htm

Aydın, İ. H. (2006). Bir felsefi metafor: yolda olmak. Dinbilimleri Akademik Araştırma Dergisi, 6(4), 9-22. http://www.dinbilimleri.com/OncekiSayilar.aspx adresinden alınmıştır.

Boostrom, R. (1998). Safe spaces: reflections on an educational metaphor. Journal of Curriculum Studies, 30(4), 397-408.

Çağırgan Gülten, D. \& Batdal Karaduman, G. (2010). İlköğretim matematik öğretmen adaylarının eğitim süreci hakkındaki felsefi tercihleri ve ögretmenlik mesleğine yönelik tutumlart. International Conference on New Trends in Education and Their Implications Kongresi, Ankara, Türkiye.

Doğanay A. \& Sarı, M. (2003). İlköğretim öğretmenlerinin sahip oldukları eğitim felsefelerine ilişkin algıların değerlendirilmesi: öğretmenlerin eğitim felsefeleri. Türk Ĕ̈itim Bilimleri Dergisi, 1(3), 321-337.

Duman, B. \& Ulubey, Ö. (2008). Öğretmen adaylarının benimsedikleri eğitim felsefelerinin öğretim teknolojilerini ve interneti kullanma düzeylerine etkisi ile ilgili görüşleri. Muğla Üniversitesi Sosyal Bilimler Enstitüsü Dergisi, 20, 95114.

Ergün, M. \& Yapıc1, M. (2006). Öğretmen adaylarının felsefe derslerine ilişkin görüşleri. III. Uluslararası Öğretmen Yetiştirme Sempozyumu, Çanakkale On Sekiz Mart Üniversitesi, Çanakkale, Türkiye.

Forceville, C. (2002). The identification of target and source in pictorial metaphors. Journal of Pragmatics, 34, 1-14.

Güler, A. (2008). Eğitimin tarihi, sosyal ve felsefi temelleri (1. baskı). Punto tasarım.

Hesapçığlu, M. (2011). Öğretim ilke ve yöntemleri: Ĕ̆itim programlarl ve ögretim (7. bask1). Ankara: Nobel Yayınlar1.

Kuçuradi, İ. (1996). Felsefe açısından eğitim ve Türkiye'de eğitim. Açış Konuşması Seminer Bildirileri, Türkiye Felsefe Kurumu, Ankara, Türkiye.

Lakoff, G. \& Johnson M. (2005). Metaforlar: hayat, anlam ve dil (G. Y. Demir, Çev.). İstanbul: Paradigma Yayınları.

Levine, P.M. (2005). Metaphors and images of classrooms, 41(4), 172-175. http://eric.ed.gov/?id= EJ724893 adresinden alınmıştır.

Milli Eğitim Bakanlığı. (2009). Felsefe dersi ögretim programı. Ankara: MEB Yayını. 
Miles, M.B. \& Huberman, A. M. (1994). Qualitative data analysis: An expanded sourcebook. USA: SAGE.

Morgan, G. (1998). Yönetim ve örgüt teorilerinde metafor. İstanbul: Mess Yayınlar1.

Özlem, D. (1997). Günümüzde felsefe disiplinleri (D. Özlem, Çev.). İstanbul: İnkılap Kitapevi.

Salman, Y. (Kasım 2003). Dilin düş evreni: eğretileme. Kitap-lık Dergisi, 65, 53-54. İstanbul: Yapı Kredi Yayınları.

Sözer, E. (2008). Eğitimin felsefi femelleri. In M. Gültekin (Ed.), Eğitim bilimine giriş (s. 59-75). Anadolu Üniversitesi Açıöğretim Yayını.

Topdemir, H. G. (2009). Felsefe nedir? Bilgi nedir? Türk Kütüphaneciliği, 23(1), 119133.

Yıldırım, A. \& Şimşek, H. (2006). Sosyal bilimlerde nitel araştırma yöntemleri (6. bask1). Ankara: Seçkin Yayınevi. 